\title{
Physico-chemical Characteristics of Selected Jackfruit (Artocarpus Heterophyllus Lam) Varieties
}

\author{
J. Balamaze ${ }^{1}$, J. H. Muyonga ${ }^{1} \&$ Y. B. Byaruhanga ${ }^{1}$ \\ ${ }^{1}$ Department of Food Technology and Nutrition, School of Food Technology, Nutrition and Bio Engineering, \\ Makerere University, P. O. Box 7062 Kampala, Uganda \\ Correspondence: Yusuf Byaruhanga, Department of Food Technology and Nutrition, School of Food Technology, \\ Nutrition and Bio Engineering, Makerere University, P. O. Box 7062 Kampala, Uganda. Tel: 256-772-445-113. \\ E-mail: ybbyaru@gmail.com / ybbyaruhanga@caes.mak.ac.ug
}

Received: April 13, 2019

Accepted: May 4, 2019 Online Published: May 29, 2019

doi:10.5539/jfr.v8n4p11

URL: https://doi.org/10.5539/jfr.v8n4p11

\begin{abstract}
This study was aimed at establishing the variation in physico-chemical properties between and within different jackfruit varieties.

Mature jackfruits from trees known to produce orange, yellow and white flakes were harvested and ripened at $28^{\circ} \mathrm{C}$ and $90 \%$ relative humidity. The weight, length and circumference of ripe fruits were measured. The fruits were cut into three equal sections: top, middle and bottom. Each section was separated into flakes, rind, abortive perigones, consolidated perigones, seeds and core. The percent weight of different fruit parts, and flake physico-chemical characteristics were determined.

The average weight, length, circumference and maturation period for jackfruit varieties studied were $12 \mathrm{~kg}, 47$ $\mathrm{cm}, 76 \mathrm{~cm}$ and 104 days, respectively. The mean proportions of flakes, rind, abortive perigones, consolidated perigones, seeds and core were 24.7, 20.0, 14.5 14.3, 13.1 and 11.3\%, respectively. Ascorbic acid (AA), carotenoids, total soluble solids (TSS), TSS: acid ratio, color and texture varied significantly among jackfruit sections. Color did not vary among sections of yellow and white flaked varieties. Flake texture (hardness) was $12.1,10.5$ and $6.6 \mathrm{~N} / \mathrm{mm}$ for the white, yellow and orange flaked varieties, respectively. Flake textural resilience was in the order: white > yellow > orange flakes. Principle component analysis showed white flakes correlated positively with flake resilience, hardness and color lightness. Orange flakes were associated with high carotenoids and TSS content. Yellow flakes exhibited intermediate properties between those of white and orange flakes. Jackfruit flake color and section can be used as flake quality predictor.
\end{abstract}

Keywords: jackfruit, Artocarpus heterophyllus lam, physico-chemical, texture, fruit characteristics

\section{Introduction}

Jackfruit (Artocarpus heterophyllus lam) is the largest tree born fruit, constituting edible flakes and an inedible portion both of which can be processed into value added products. The flakes can be processed into products like juice, jam, dried chips, fruit leathers and wines, while the inedible portion could be utilized as a source of pectin. Pectin is important ingredient in the food and pharmaceutical industries where it can be used as a gelling agent, stabilizer, thickener or emulsifier (Beguma, Azizb, Uddinb, \& Yusof, 2014).

The propagation of jackfruit is mainly through seed planting. Besides, jackfruit undergoes extensive cross pollination (Mitra \& Mani, 2000), which leads to a lot of variation in fruit characteristics. Such variation may affect the quality of products processed from fruits from different jackfruit varieties. According to Balamaze, Muyonga \& Byaruhanga (2019), there are mainly three jackfruit varieties based on flake color in Uganda. Mostly, jackfruit flakes are mainly consumed fresh with the inedible fruit portions wasted or fed to animals. Farmers with jackfruit trees reported losses of up to $20 \%$ during peak harvest season (Balamaze et al., 2019). It is therefore, necessary that alternative approaches for utilization of jackfruit be evaluated to ensure full realization of the economic potential of the different jackfruit varieties. This requires a comprehensive understanding of the physico-chemical properties of the different jackfruit varieties.

Several studies on characterization of jackfruit have been undertaken; Jagaseesh, Reddy, Basavaraj, Swamy, \& Laxminarayan (2010) categorized jackfruits based on fruit size, taste, odour of flakes, shape and density of 
spines on the rind. Singh \& Srivastava (2000) identified jackfruit types based on fruit bearing habits, yield and period the fruit takes to mature. Mitra \& Mani (2000) reported jackfruit types with total soluble solutes (TSS) greater than $25^{\circ}$ brix to be more suitable for preparing desserts. Mannan, Gazi \& Mia (2006) studied variation in physical properties of jackfruits during off season periods and significant variations were found among the germplasms in relation to fruit characteristics. Reddy, Patil, Kumar, \& Govindaraju (2004) reported that among the qualitative characters studied, TSS was more variable in jackfruit clones. Ullah \& Haque, (2008) reported wide variation in the period a fruit takes to mature ranging between 82 and 160 days. Rosnah, Chia, Chin, Noraziah, \& Osman, (2009) reported the changes in the chemical composition as well as variation in pH, TSS and Titratable acidity (TA) of the jackfruit cultivar J33 during ripening and storage. Sakimin, Patre, Jurami, Alami \& Aslan (2017) observed a significant increase in firmness for flakes treated with ascorbic acid under cold storage.

In spite of several studies previously conducted on jackfruit, there is a dearth of information on the relationship between jackfruit flake color and their physico-chemical characteristics. A detailed understanding of jackfruit characteristics based on flake color would be an important guide for identifying jackfruit varieties for particular industrial process applications. This study therefore, aimed at establishing whole jackfruit dimensions, fruit part proportions and physico-chemical properties of flakes from different jackfruit varieties.

\section{Material and Methods}

\subsection{Experimental Design}

Three jackfruit trees from each variety known to produce yellow, orange and white flakes were selected, marked and secured in the same locality of Malangala sub-county in Mityana District, Uganda. On each of the identified jackfruit trees, female fruit sets were randomly selected and identified according to Ullah and Haque (2008). The fruit sets were coded to identify the fruit by: fruit set date, flake color and number. The code was sealed in an impervious transparent plastic material to prevent moisture destroying the label. For each jackfruit variety studied, a total of 20 coded fruits were selected and divided into 2 sets of 10 fruits each; the first set was for studying the physico-chemical characteristics of the fruit and the second was for determination of maturation period of the different jackfruit varieties. The jackfruit varieties and sections were the independent variables while the jackfruit parts and flake physico-chemical properties were the dependent variables. The experiment and analyses was done in triplicates.

\subsection{Sampling}

The first set of fruits for determining the maturation period were left on the tree and monitored until they ripened. The number of days, from fruit set, a particular fruit took to mature and ripen were recorded. A ripe fruit was identified by a deep hollow or empty vessel sound produced when tapped by hand.

The second set was for determining fruit part proportions and flakes' physico chemical characteristics. Jackfruits for this purpose were harvested mature green; fruits were considered mature when the last leaf on the fruit stalk turned yellow, rind spine flattened and when the fruit skin color became pale (APAARI, 2012). Three mature fruits from each of the selected trees were harvested avoiding them to hit the ground. The fruits were transported on the same day to the laboratory. The fruits were kept covered in wooden boxes for 2 days at $28^{\circ} \mathrm{C}$ and $90 \% \mathrm{RH}$. This was to allow uniform ripening of the fruits before analysis.

\subsection{Whole Fruit Dimension and Section Proportion Determination}

Ripe fruits were washed using tap water. The adhering water after washing was flushed off using a jet of compressed air. The fruits were weighed using a weighing scale (Adam equipment CBK32, Johannesburg, South Africa) and the weight (kilograms) was recorded. The fruit length and cross sectional circumference (centimeters) measured from top to bottom and at the middle point of the fruits, respectively were determined using a measuring tape. The fruits were transversely sectioned using a stainless steel knife into three equal sections labeled as top, middle and bottom (Ong, et al., 2006). The distal section of fruit that is attached to the plant was considered as the top section while the proximal section was considered as the bottom. Each section was coded, weighed and then divided into four equal quarters to facilitate separation into parts including: core/rachis, seeds, flakes/bulbs without seeds, abortive perigones/rags, rind and consolidated perigones. The parts were separately weighed and the proportion of each part for a jackfruit section was calculated and expressed as percentage of the total weight of the section.

\subsection{Determination of Physical Properties of Jackfruit Flakes}

Two flake samples of about $150 \mathrm{~g}$ each were separately picked from each section of the three different jackfruit varieties. The two samples were respectively used for determining physical and chemical properties, of the flakes following the procedures described in the following sections. 


\subsubsection{Thickness, Length and Breadth of Flakes}

Flake thickness was determined using a micrometer screw gauge (N8/32, New Delhi, India) and the values were recorded in centimeters. The length and breadth of the flakes were taken using Vanier calipers (KBD Tolls Jiangsu China) and values were recorded in centimeters.

\subsubsection{Flake Color Measurement}

The color intensity parameters $\mathrm{L}^{*}, \mathrm{a}^{*}$ and $\mathrm{b}^{*}$ for the flake were determined using a Lovibond Tintometer L322/92E, Salisbury, England). The lightness value $\left(\mathrm{L}^{*}\right)$ represents the black-white colors, $\mathrm{a}^{*}$ represents the green-red colors and $\mathrm{b}^{*}$ represents the blue-yellow colors.

\subsubsection{Textural Properties (Hardness and Resilience) of Flakes}

A uniform flake sample of $1 \mathrm{~cm}^{2}$ was used to prepare samples for texture analysis. Textural properties were measured using a texture analyzer (model TA.XT- Plus Stable Micro System, Ltd Godalming, Surrey, UK) with a $2 \mathrm{~kg}$ load cell fitted with a light knife blade (A/LKB) probe. The probe was operated in compression mode with a trigger force of $0.049 \mathrm{~N}$, pre-test speed $1 \mathrm{~mm} / \mathrm{sec}$, test speed $2 \mathrm{~mm} / \mathrm{sec}$, a return speed of $10 \mathrm{~mm} / \mathrm{sec}$ and penetration distance of $0.29 \mathrm{~cm}$. Hardness was considered to be the initial force $(\mathrm{N})$ needed for the TA probe to cut through the flake skin and was expressed in Newtons $(\mathrm{N})$ represented by the peak value on the graph. Resilience was considered to be the total force needed for the TA probe to cut through a penetration depth of $0.29 \mathrm{~cm}$ into the flake. Resilience was expressed as the area under the curve.

\subsection{Determination of Chemical Properties of Jackfruit Flakes}

\subsubsection{Titratable Acidity and $\mathrm{pH}$}

Titratable acidity was determined according to the method described by Rangana (1995) with modifications. A $50 \mathrm{~g}$ portion of jackfruit flakes was homogenized using Robot Blender (H-Biaugeaud R23 Beauduex France). A $10 \mathrm{~g}$ sample of the homogenized flakes was mixed with $25 \mathrm{~mL}$ of distilled water and titrated against $0.1 \mathrm{~N} \mathrm{NaOH}$ using phenolphthalein indicator. The end point was a faint pink color and the results were expressed as percentage citric acid equivalent. The $\mathrm{pH}$ of the homogenized flakes was measured directly using a $\mathrm{pH}$ meter (Model HI 221, HANNA Instruments Ltd, Bedford, UK).

\subsubsection{Total Soluble Solids (TSS) and TSS: Acid Ratio}

Total soluble solids was determined using a hand held refractometer (Abbe 315RS, Royal Tunbridge Wells, UK). TSS: Acid ratio was calculated by dividing the TSS value by the titratable acid value.

\subsubsection{Vitamin C}

Vitamin C content was determined according to AOAC (1995) with modifications. One hundred grams of flakes were homogenized using a blender and $100 \mathrm{~mL}$ of $4 \%$ Trichloroacetic acid were added. The mixture was filtered and $5 \mathrm{~mL}$ of filtrate were made-up to $10 \mathrm{~mL}$ with $4 \%$ Trichloroacetic acid solution. This solution was titrated against $0.01 \%$ 2, 6-dichloro-phenol-indophenol solution which was freshly standardized using $0.05 \%$ ascorbic acid solution. The end point was marked by a transient pink color which persisted for $15 \mathrm{~s}$. All chemicals and reagents were obtained from Sigma (Sigma-Aldrich, New Jersey, USA).

\subsubsection{Total Carotenoids}

Total carotenoids content was determined according to Pinheiro-santana, Stringheta, Branda, Paez, \& Queiroz (1998) with modifications. Five grams of flakes were ground, in a clean mortar, to a fine pulp and $20 \mathrm{ml}$ of $80 \%$ acetone were added. The extract was centrifuged at 5,000 $\times \mathrm{g}$ for $5 \mathrm{~min}$ and the supernatant was transferred to a $100 \mathrm{ml}$ volumetric flask. The residue was ground with additional $20 \mathrm{ml}$ of $80 \%$ acetone, centrifuged at 5,000 $\times \mathrm{g}$ for $5 \mathrm{~min}$ and the supernatant was transferred to the same flask. This process was repeated until the residue was colorless. The pestle and mortar were washed thoroughly with $80 \%$ acetone and washings were collected in the same flask and filtered through glass wool lined by a layer of sodium sulphate crystals to remove traces of water. The final volume was made-up to $100 \mathrm{ml}$ with $80 \%$ acetone and the absorbance was read at $450 \mathrm{~nm}$ for the sample and blank (80\% acetone). The carotenoids were determined and expressed in mg per $100 \mathrm{~g}$ of pulp on fresh sample.

\subsubsection{Dry Matter}

Dry matter content was determined according to Robert \& Bradley (2010) with modification. Accordingly, 2-6 g of sample was weighed and dried overnight at $80^{\circ} \mathrm{C}$ in an air forced oven (Ov123 Gallakamp, England). The dry matter content was calculated by expressing the dried sample weight as a percentage of the wet sample weight using the equation below. 


$$
\text { Dry matter }=\frac{\text { Total Dry weight of the sample }}{\text { Total fresh weight of the sample }} \times 100
$$

\subsection{Data Analysis}

Statistical analyses were performed using SAS University edition software local host 10080 . Means were compared by Analysis of Variance (ANOVA) and separated by Tukey Post hoc test (with $p=0.05$ ). In order to visualize and analyze the overall variability present in the data, the same data used for mean separation were subjected to multivariate principal component analysis (PCA). The PCA was performed taking into consideration 14 main parameters i.e. dry matter, titratable acidity, ascorbic acid, total soluble solids, carotenoids, TSS: TA ratio, flake width, length, thickness, hardness, resilience, $\mathrm{L}^{*}, \mathrm{~b}^{*}$ and $\mathrm{a}^{*}$. The general variability in jackfruit flakes characteristics was visualized on a 2D-PCA. New orthogonal coordinates explaining the biggest variability in the same data were selected. Additionally, the loadings, which are distances from the center to a variable location showed the distribution of different variables in the unit plot of the two PCs whereas, the Eigen value scores for each observation (section) showed the location of different jackfruit sections in relation to variables.

\section{Results}

\subsection{Dimensional and Maturation Characteristics of the Whole Jackfruits}

Significant differences were observed in the weight length and circumference of the different jackfruit varieties. In terms of weight and circumference, yellow flaked jackfruits were significantly heavier and larger in circumference $(p<0.05)$ than the white and orange flaked fruits. The white flaked jackfruits took a significantly longer period to mature than either the yellow or orange flaked jackfruits (Table 1). The yellow flaked fruits were longer than the white and orange. Generally, the orange flaked jackfruit variety was relatively smaller in all aspects and took relatively a shorter period of time to mature compared to the white and the orange flaked varieties.

Table 1. Mean dimensions and maturation time of three jackfruit varieties

\begin{tabular}{lllll}
\hline Variety/Flake color & Mass $(\mathbf{K g})$ & Length $(\mathbf{c m})$ & Circumference $(\mathbf{c m})$ & Maturation period (days) \\
\hline Yellow & $17.0^{\mathrm{a}^{*}} \pm 5.6^{\dagger}$ & $51.9^{\mathrm{a}} \pm 3.6$ & $81.9^{\mathrm{a}} \pm 3.3$ & $105.0^{\mathrm{b}} \pm 2.0$ \\
White & $11.0^{\mathrm{b}} \pm 2.0$ & $46.1^{\mathrm{b}} \pm 2.8$ & $77.3^{\mathrm{c}} \pm 1.6$ & $113.0^{\mathrm{a}} \pm 1.7$ \\
Orange & $8.7^{\mathrm{b}} \pm 1.5$ & $43.3^{\mathrm{b}} \pm 2.5$ & $68.5^{\mathrm{b}} \pm 1.6$ & $95.0^{\mathrm{c}} \pm 2.0$ \\
Overall average & $12.0 \pm 4.0$ & $47.0 \pm 4.5$ & $76.0 \pm 7.0$ & $104.0 \pm 5.0$ \\
\hline
\end{tabular}

* Mean values with the same superscripts in the same column are not significantly different

${ }^{\dagger} \pm$ values are standard deviation of the mean

\subsection{Seeds, Core, Perigone, Flake and Rind Proportions of Different Jackfruit Sections}

There were significant differences in seeds, core, abortive perigones and flakes proportions among different jackfruit varieties and fruit sections. The middle section of the orange flaked jackfruit variety had more seeds than the bottom and the top. For the white flaked jackfruits, the bottom section had significantly lower seeds than the middle and top sections of the same fruit. Variation in the core proportion based on fruit sections was also observed. The middle section of all jackfruits varieties studied had relatively more core proportion than the bottom and the top sections (Table 2).

The abortive perigones were higher in middle section of yellow flaked fruits while the lowest proportion was observed in top and bottom sections of white and orange flaked fruits, respectively. Flakes were highest in the middle section of orange flaked jackfruits, however, the distribution of flakes among sections did not exhibit a particular trend. The rind and consolidated perigones did not vary significantly among fruit sections (Table 2). The jackfruit type affected some fruit proportions. The mean flake proportion was higher in orange flaked variety $(29.6 \%)$ compared to white and yellow which had $23.1 \%$ and $21.4 \%$, respectively. The seeds were generally higher in orange flaked jackfruit while the white flaked jackfruit exhibited the least seed proportion. The proportion of the core was higher in white flaked variety whereas, the abortive perigones were higher in the yellow flaked variety. However, the rind proportion did not vary significantly among fruit varieties. 
Table 2. Percent proportion of fruit parts from different fruit of three jackfruit varieties

\begin{tabular}{llllllll}
\hline Variety/Flake color & Section & Seed & Rind & Consolidated perigones & Core & Abortive perigones & Flakes \\
\hline Yellow & Top & $11.5^{\mathrm{b}^{\mathrm{w}}} \pm 0.3^{\dagger}$ & $19.3^{\mathrm{a}} \pm 0.1$ & $15.8^{\mathrm{a}} \pm 2.1$ & $8.5^{\mathrm{a}} \pm 1.0$ & $16.0^{\mathrm{c}} \pm 0.4$ & $19.3^{\mathrm{c}} \pm 1.2$ \\
& Middle & $13.3^{\mathrm{b}} \pm 0.2$ & $16.6^{\mathrm{a}} \pm 0.3$ & $14.4^{\mathrm{a}} \pm 2.5$ & $13.5^{\mathrm{b}} \pm 1.9$ & $17.8^{\mathrm{a}} \pm 2.0$ & $23.5^{\mathrm{b}} \pm 7.3$ \\
\multirow{3}{*}{ White } & Bottom & $12.2^{\mathrm{b}} \pm 0.6$ & $22.8^{\mathrm{a}} \pm 1.7$ & $15.5^{\mathrm{a}} \pm 1.1$ & $11.9^{\mathrm{d}} \pm 2.6$ & $15.5^{\mathrm{c}} \pm 1.6$ & $21.5^{\mathrm{c}} \pm 1.9$ \\
& Top & $11.3^{\mathrm{b}} \pm 0.7$ & $20.7^{\mathrm{a}} \pm 2.4$ & $15.0^{\mathrm{a}} \pm 0.5$ & $8.9^{\mathrm{f}} \pm 0.2$ & $12.9^{\mathrm{d}} \pm 0.7$ & $26.6^{\mathrm{b} \pm 1.0}$ \\
& Middle & $11.2^{\mathrm{b}} \pm 0.9$ & $17.6^{\mathrm{a}} \pm 0.6$ & $13.5^{\mathrm{a}} \pm 1.0$ & $12.7^{\mathrm{b}} \pm 0.7$ & $13.3^{\mathrm{d}} \pm 0.6$ & $25.1^{\mathrm{b}} \pm 2.2$ \\
Orange & Bottom & $9.1^{\mathrm{c}} \pm 0.7$ & $24.2^{\mathrm{a}} \pm 2.2$ & $17.1^{\mathrm{a}} \pm 1.1$ & $12.0^{\mathrm{c}} \pm 0.9$ & $14.8^{\mathrm{c}} \pm 0.8$ & $17.8^{\mathrm{c}} \pm 2.2$ \\
& Top & $13.0^{\mathrm{b}} \pm 0.4$ & $18.0^{\mathrm{a}} \pm 5.1$ & $13.0^{\mathrm{a}} \pm 3.3$ & $8.1^{\mathrm{g}} \pm 1.7$ & $14.3^{\mathrm{e}} \pm 0.5$ & $26.7^{\mathrm{b}} \pm 3.3$ \\
& Middle & $17.3^{\mathrm{a}} \pm 0.4$ & $21.3^{\mathrm{a}} \pm 6.3$ & $15.7^{\mathrm{a}} \pm 3.9$ & $15.0^{\mathrm{a}} \pm 4.0$ & $16.7^{\mathrm{b}} \pm 0.6$ & $39.5^{\mathrm{a}} \pm 5.2$ \\
& Bottom & $9.1^{\mathrm{c}} \pm 2.0$ & $20.6^{\mathrm{a}} \pm 6.3$ & $14.2^{\mathrm{a}} \pm 5.0$ & $11.0^{\mathrm{e}} \pm 1.4$ & $12.7^{\mathrm{d}} \pm 0.9$ & $22.7^{\mathrm{b}} \pm 8.7$ \\
\hline
\end{tabular}

*Mean values with the same superscripts in the same column are not significantly different

${ }^{\dagger} \pm$ values are standard deviation of the mean.

Flakes from the white flaked jackfruits were smaller in size than those from the orange or yellow flaked jackfruits. With respect to fruit sections, flakes from the middle section of the yellow flaked jackfruit were larger in size compared to flakes from other sections. There were minor differences in lightness among flakes from different sections, this was exhibited in flakes from the bottom section of white flaked fruits and orange flakes from the different sections. Flake redness on the other hand was highest and significantly varied only in orange flaked jackfruits sections. The degree of yellowness was lower in flakes from the bottom of white flaked jackfruits and higher in top and middle sections of yellow flaked jackfruits. The degree of yellowness did not differ significantly among jackfruit sections of the same fruit (Table 3).

Table 3. Physical properties of flakes from different sections of three jackfruit varieties

\begin{tabular}{llcccccc}
\hline \multirow{2}{*}{ Variety/Flake color } & \multirow{2}{*}{ Section } & Length $(\mathbf{c m})$ & \multirow{2}{*}{ Breadth $(\mathbf{c m})$} & \multirow{2}{*}{ Thickness $(\mathbf{c m})$} & \multicolumn{3}{c}{ Color } \\
\cline { 6 - 8 } & & & & $\mathbf{L}^{*}$ & $\mathbf{a}^{*}$ & $\mathbf{b}^{*}$ \\
Yellow & Top & $5.8^{\mathrm{a}^{\mathrm{*}}} \pm 0.6^{\dagger}$ & $3.3^{\mathrm{c}} \pm 0.2$ & $0.4^{\mathrm{ab}} \pm 0.1$ & $88.7^{\mathrm{abc}} \pm 6.7$ & $-17.9^{\mathrm{a}} \pm 4.1$ & $92.9^{\mathrm{b}} \pm 1.0$ \\
& Middle & $6.0^{\mathrm{a}} \pm 1.2$ & $3.7^{\mathrm{a}} \pm 0.1$ & $0.3^{\mathrm{ab}} \pm 0.1$ & $92.5^{\mathrm{ab}} \pm 5.1$ & $-18.5^{\mathrm{a}^{\mathrm{a}} \pm 1.9}$ & $92.6^{\mathrm{b}} \pm 1.1$ \\
& Bottom & $5.4^{\mathrm{a}} \pm 0.6$ & $3.2^{\mathrm{c}} \pm 0.2$ & $0.3^{\mathrm{ab}} \pm 0.1$ & $93.0^{\mathrm{ab}} \pm 3.3$ & $-19.8^{\mathrm{a}^{\mathrm{a}} \pm 2.8}$ & $91.0^{\mathrm{ab}} \pm 6.9$ \\
White & Top & $5.5^{\mathrm{a}} \pm 0.9$ & $3.0^{\mathrm{b}} \pm 0.2$ & $0.4^{\mathrm{ab}} \pm 0.1$ & $93.1^{\mathrm{ab}} \pm 8.1$ & $-23.6^{\mathrm{ab}} \pm 1.1$ & $86.8^{\mathrm{ab}} \pm 3.7$ \\
& Middle & $5.1^{\mathrm{a}} \pm 0.7$ & $3.0^{\mathrm{b}} \pm 0.2$ & $0.5^{\mathrm{ab}} \pm 0.1$ & $95.1^{\mathrm{bc}} \pm 1.1$ & $-23.8^{\mathrm{ab}} \pm 2.7$ & $86.6^{\mathrm{ab}} \pm 3.9$ \\
& bottom & $5.2^{\mathrm{a}} \pm 0.6$ & $3.1^{\mathrm{b}} \pm 0.2$ & $0.4^{\mathrm{ab}} \pm 0.1$ & $96.0^{\mathrm{c}} \pm 1.1$ & $-24.9^{\mathrm{ab}} \pm 2.5$ & $84.5^{\mathrm{a}} \pm 7.1$ \\
Orange & Top & $5.3^{\mathrm{a}} \pm 1.1$ & $3.2^{\mathrm{c}} \pm 0.2$ & $0.4^{\mathrm{ab}} \pm 0.1$ & $85.0^{\mathrm{a}} \pm 8.3$ & $-6.3^{\mathrm{c}} \pm 6.5$ & $90.5^{\mathrm{ab}} \pm 2.8$ \\
& Middle & $5.5^{\mathrm{a}} \pm 1.1$ & $3.4^{\mathrm{a}} \pm 0.4$ & $0.4^{\mathrm{ab}} \pm 0.1$ & $86.9^{\mathrm{b}} \pm 5.3$ & $-7.8^{\mathrm{d}} \pm 8.9$ & $90.3^{\mathrm{ab}} \pm 4.2$ \\
& Bottom & $5.5^{\mathrm{a}} \pm 0.8$ & $3.5^{\mathrm{a}} \pm 0.4$ & $0.4^{\mathrm{ab}} \pm 0.1$ & $87.4^{\mathrm{ab}} \pm 5.0$ & $-9.4^{\mathrm{cd}} \pm 8.8$ & $87.0^{\mathrm{ab}} \pm 5.4$ \\
\hline
\end{tabular}

*Mean values with the same superscripts in the same column are not significantly different.

${ }^{\dagger} \pm$ values are standard deviation of the mean.

$\mathrm{L}^{*}=$ lightness, $\mathrm{a}^{*}=$ redness, $\mathrm{b}^{*}=$ yellowness

\subsection{Textural Properties of Jackfruit Flakes}

Hardness and resilience of the flakes varied significantly among white, yellow and orange flaked jackfruits (Table 4). In general, orange flaked variety was significantly softer with a mean hardness of $6.6 \mathrm{~N}$ compared to the yellow and white flaked varieties, which exhibited a mean hardness of $10.5 \mathrm{~N}$ and $12.1 \mathrm{~N}$, respectively. Although resilience followed the same trend as flake hardness, it exhibited relatively higher mean force values of 7.7, 11.6 and $13.4 \mathrm{~N}$ for orange yellow and white flaked varieties, respectively. Jackfruit sections affected flake hardness and resilience, with flakes from the top sections exhibiting a relatively softer texture than those from the middle and bottom sections of the same fruit variety (Table 4). 
Table 4. Textural characteristics of flakes from different sections of three jackfruit types

\begin{tabular}{llll}
\hline Variety/Flake color & Section & Hardness $(\mathbf{N})$ & Resilience $(\mathbf{N} / \mathbf{m m})$ \\
\hline Yellow & Top & $8.1^{\mathrm{de}} \pm 0.6^{\dagger}$ & $9.3^{\mathrm{de}} \pm 1.1$ \\
& Middle & $10.9^{\mathrm{bc}} \pm 1.4$ & $12.0^{\mathrm{bc}} \pm 1.3$ \\
White & Bottom & $12.5^{\mathrm{ab}} \pm 1.0$ & $13.6^{\mathrm{abc}} \pm 1.0$ \\
& Top & $9.7^{\mathrm{cd}} \pm 1.4$ & $11.3^{\mathrm{cd}} \pm 1.5$ \\
& Middle & $12.8^{\mathrm{ab}} \pm 0.9$ & $13.8^{\mathrm{ab}} \pm 1.1$ \\
Orange & Bottom & $13.9^{\mathrm{a}} \pm 0.8$ & $15.3^{\mathrm{a}} \pm 1.0$ \\
& Top & $5.5^{\mathrm{f}} \pm 1.0$ & $6.4^{\mathrm{g}} \pm 1.1$ \\
& Middle & $6.6^{\mathrm{d}} \pm 0.3$ & $7.8^{\mathrm{ef}} \pm 1.3$ \\
& Bottom & $7.9^{\mathrm{d}} \pm 2.4$ & $9.1^{\mathrm{de}} \pm 2.0$ \\
\hline
\end{tabular}

*Mean values with the same superscripts in the same column are not significantly different.

${ }^{\dagger} \pm$ values are standard deviation of the mean.

\subsection{Chemical Properties of Jackfruit Flakes}

Jackfruit variety affected titratable acidity of flakes. White flaked variety had relatively lower TA than the yellow and orange flaked varieties. Flake $\mathrm{pH}$, on the other hand, remained fairly constant among different jackfruit varieties. Total soluble solutes varied significantly among jackfruit varieties, with orange varieties showing relatively higher total soluble solids values than white flaked variety. With respect to TSS:acid ratio, orange flaked variety exhibited relatively high ratio than yellow and white flaked variety. Regarding ascorbic acid, yellow flaked variety had significantly lower AA than other varieties. Carotenoids were highest in the orange flaked variety. The dry matter content did not vary among flakes from the different jackfruit varieties (Table 5). Titratable acidity varied among different fruit sections. The white flaked variety had significantly lower titratable acidity in the top and middle sections compared to sections of other fruit types. The pH and TSS did not vary significantly among flakes from different fruit sections. TSS:TA ratio decreased from top to bottom sections in all fruit varieties. Ascorbic acid, carotenoids and dry matter content did not vary significantly among fruit sections (Table 5).

Table 5. Chemical composition of flakes from different sections of three jackfruit varieties

\begin{tabular}{|c|c|c|c|c|c|c|c|c|}
\hline $\begin{array}{l}\text { Variety/Flake } \\
\text { color }\end{array}$ & $\begin{array}{l}\text { Fruit } \\
\text { section }\end{array}$ & $\begin{array}{l}\text { Titratable Acid } \\
(\mathrm{TA})(\mathrm{g}) / \mathbf{1 0 0}\end{array}$ & pH & $\begin{array}{l}\text { Total oluble } \\
\text { Solids (TSS) }\end{array}$ & TSS:TA & $\begin{array}{l}\text { Ascorbic } \\
\text { Acid } \\
(\mathrm{mg}) / 100\end{array}$ & $\begin{array}{l}\text { Carotenoid } \\
(\mathbf{m g}) / \mathbf{1 0 0}\end{array}$ & $\begin{array}{l}\text { Dry matter } \\
\text { Content } \\
(\mathrm{g}) / \mathbf{1 0 0}\end{array}$ \\
\hline \multirow[t]{3}{*}{ Yellow } & Top & $0.38^{\mathrm{a}^{*}} \pm 0.1^{\dagger}$ & $5.1^{\mathrm{ab}} \pm 0.5$ & $24.3^{\mathrm{ab}} \pm 1.9$ & $63.7^{\mathrm{a}} \pm 3.0$ & $2.1^{\mathrm{bc}} \pm 0.4$ & $0.6^{\mathrm{b}} \pm 0.1$ & $25.7^{\mathrm{a}} \pm 5.1$ \\
\hline & Middle & $0.40^{\mathrm{a}} \pm 0.1$ & $5.0^{\mathrm{ab}} \pm 0.6$ & $22.4^{\mathrm{bc}} \pm 2.1$ & $56.0^{\mathrm{ab}} \pm 3.3$ & $2.0^{\mathrm{bc}} \pm 0.5$ & $0.5^{\mathrm{b}} \pm 0.1$ & $25.5^{\mathrm{a}} \pm 2.3$ \\
\hline & Bottom & $0.44^{\mathrm{a}} \pm 0.1$ & $\begin{array}{l}4.6 \quad \mathrm{~b} \\
\pm 0.3\end{array}$ & $20.9^{\mathrm{cd}} \pm 2.3$ & $47.5^{\mathrm{c}} \pm 3.9$ & $1.6^{\mathrm{c}} \pm 0.5$ & $0.5^{\mathrm{b}} \pm 0.1$ & $23.9^{\mathrm{a}} \pm 7.7$ \\
\hline \multirow[t]{3}{*}{ White } & Top & $0.32^{\mathrm{b}} \pm 0.1$ & $5.2^{\mathrm{ab}} \pm 0.3$ & $19.4^{\mathrm{de}} \pm 0.8$ & $60.6^{\mathrm{b}} \pm 2.1$ & $3.9^{\mathrm{a}} \pm 1.2$ & $0.4^{\mathrm{b}} \pm 0.1$ & $25.4^{\mathrm{a}} \pm 0.3$ \\
\hline & Middle & $0.36^{\mathrm{b}} \pm 0.1$ & $5.4^{\mathrm{a}} \pm 0.3$ & $18.1^{\mathrm{de}} \pm 0.9$ & $50.3^{\mathrm{e}} \pm 2.5$ & $3.6^{\mathrm{ab}} \pm 1.0$ & $0.3^{b} \pm 0.1$ & $24.7^{\mathrm{a}} \pm 2.4$ \\
\hline & Bottom & $0.39^{\mathrm{a}} \pm 0.2$ & $5.5^{\mathrm{a}} \pm 0.2$ & $17.0^{\mathrm{e}} \pm 1.1$ & $43.6^{\mathrm{c}} \pm 1.9$ & $3.2^{\mathrm{ab}} \pm 0.5$ & $0.3^{b} \pm 0.1$ & $24.2^{\mathrm{a}} \pm 2.0$ \\
\hline \multirow[t]{3}{*}{ Orange } & Top & $0.40^{\mathrm{a}} \pm 0.1$ & $4.9^{\mathrm{b}} \pm 0.3$ & $25.8^{\mathrm{a}} \pm 1.0$ & $64.5^{\mathrm{f}} \pm 1.4$ & $4.3^{\mathrm{a}} \pm 1.2$ & $2.4^{\mathrm{a}} \pm 1.1$ & $25.4^{\mathrm{a}} \pm 2.8$ \\
\hline & Middle & $0.42^{\mathrm{a}} \pm 0.1$ & $5.0^{\mathrm{ab}} \pm 0.3$ & $25.7^{\mathrm{a}} \pm 1.9$ & $61.2^{\mathrm{b}} \pm 1.5$ & $3.7^{\mathrm{a}} \pm 1.0$ & $2.2^{\mathrm{a}} \pm 1.0$ & $24.5^{\mathrm{a}} \pm 3.5$ \\
\hline & Bottom & $0.43^{\mathrm{a}} \pm 0.1$ & $4.8^{\mathrm{b}} \pm 0.3$ & $25.3^{\mathrm{ab}} \pm 2.4$ & $58.3^{\mathrm{ab}} \pm 2.0$ & $3.2^{\mathrm{ab}} \pm 1.1$ & $1.8^{\mathrm{a}} \pm 1.0$ & $22.3^{\mathrm{a}} \pm 5.4$ \\
\hline
\end{tabular}

*Mean values with the same superscripts in the same column are not significantly different

${ }^{\dagger} \pm$ values are standard deviation of the mean

TSS:TA Ratio of Total Soluble Solids to Titratable acid

\subsection{Relationships between Flake Physico-chemical Properties and Fruit Sections}

The relationship was analyzed by subjecting all the flake parameters of different fruit sections of different jackfruit varieties to principle component analysis. Principle component one (PC1) and principle component two (PC2) which explained most of the variability in the flake characteristics (54\% and 18\%) respectively were selected (Figure 1). 


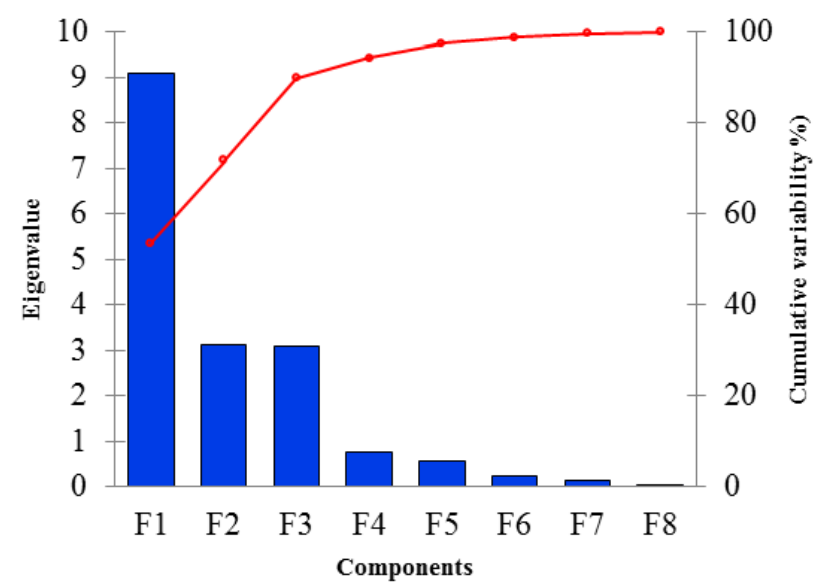

Figure 1. Screen plot of Eigen value versus Principal components

The two principal components provided a general visualization of the interrelationship between the flake physico-chemical properties and sections of different jackfruit PC1 was positively and majorly related to carotenoids, flake redness and TSS and these variables were in proximity to orange jackfruit sections on the bi-plot. Flake textural properties, flake lightness and yellowness occupied a negative location along PC1 and closely associated to white jackfruit sections. On the plot the properties of yellow flaked jackfruit were located between those of white and orange flaked jackfruit varieties (Figure 2). PC1 clearly separated the samples based on their color and textural properties and therefore the 52\% variability explained by PC1 was mainly in flake appearance and hardness. PC2 separated samples based on their dimensional characteristics; with flake thickness loaded positively and close to white jackfruit sections while yellow flakes of the yellow flaked variety were broader and elongated. PCA located jackfruit sections into three clusters (Figure 2). The orange sections (Cluster 1) were located on the positive side of $\mathrm{PC} 1$ and $\mathrm{PC} 2$, the white sections on the negative side of $\mathrm{PC} 1$ and positive part of PC2 (Cluster 2) and the yellow sections cluster occupied an intermediate position between white and orange fruit sections (Cluster 3).

\section{Biplot (axes F1 and F2: 72\%)}

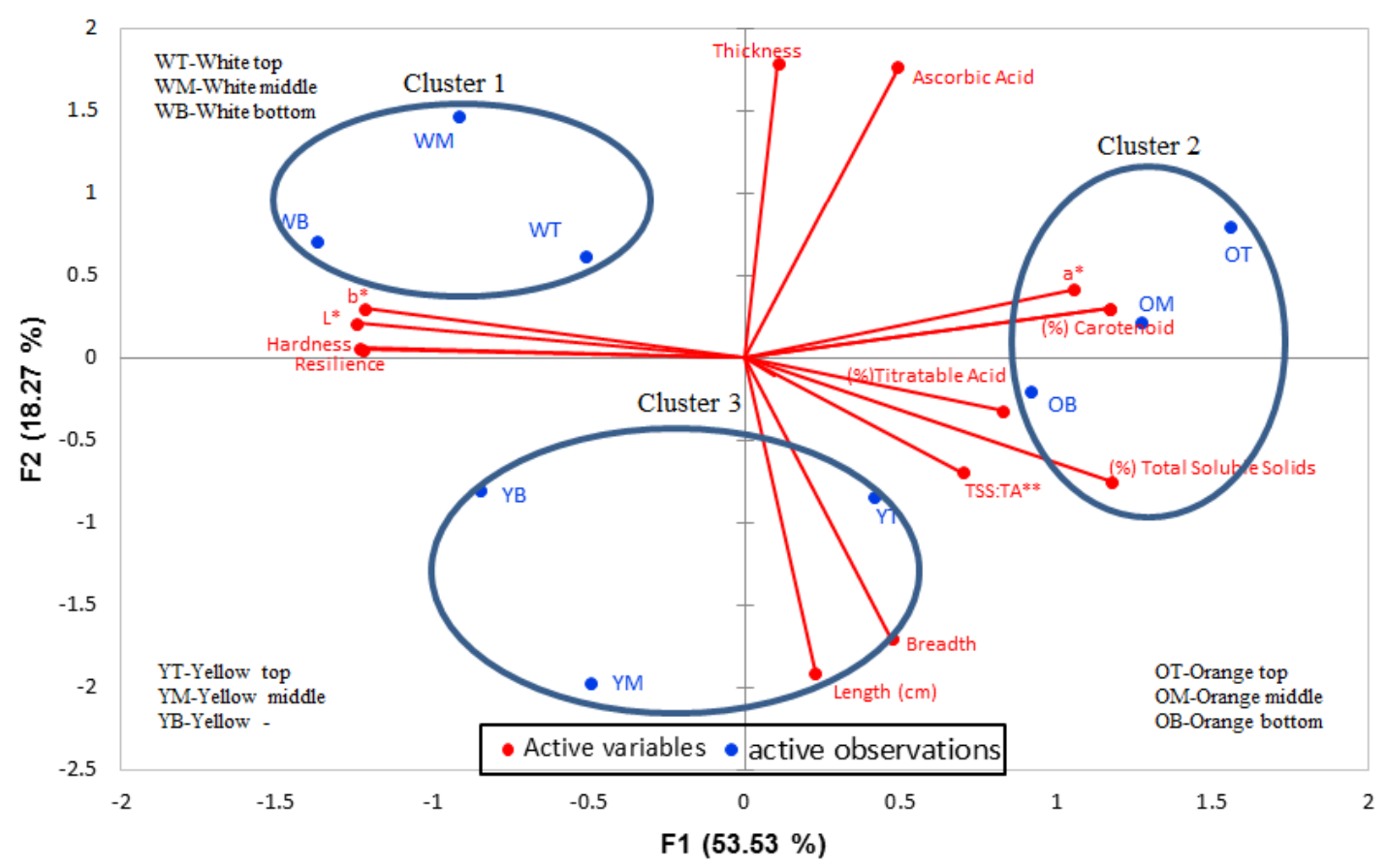

Figure 2. The interrelationship between flake physico-chemical properties and fruit sections 


\section{Discussion}

\subsection{Fruit Size, Parts Proportion and Flakes Dimension}

The jackfruit circumference of $76 \mathrm{~cm}$ observed in this study, was 1.7 times the size of jackfruit circumference reported by Sarker \& Zuberi (2011) implying that the jackfruits in the study area were generally large in size than those reported in literature. The yellow flaked jackfruits among the varieties studied had a larger fruit size with an intermediate maturation period compared to the white and orange flaked jackfruits. The difference in fruit size and maturation period observed in this study could possibly be due to genetic variation, growth conditions, weather, soil fertility and tree age. This is consistent with Azad, Jones, \& Haq (2007) who emphasized the role of genotypes in jackfruit inter-tree variation.

There was variation in the fruit proportions namely: seeds, core, abortive perigones and flakes among the three jackfruit varieties. It can also be presumed that the yellow fruit type generates more flakes and waste than the white and orange flaked jackfruits due to its larger size. However, the small size orange flaked jackfruits contained more flakes than the relatively larger yellow and white flaked varieties. This discrepancy could be attributed to genetic differences. Jagadeesh et al., (2010) reported variability among jackfruits grown in western Ghat region of India due to genetic variation. Considering flake dimensions, the breadth and thickness varied significantly for the three jackfruit varieties and were consistent with results reported by Jagadeesh et al., (2010). The authors reported 3.32, 5.71 and $0.386 \mathrm{~cm}$ for the flake breadth, length and thickness respectively. The variation observed in flake dimensions could be indicative of the greater variation existing among different jackfruit varieties caused probably by differences in genetic makeup.

\subsection{Jackfruit Flake Color \& Carotenoid Content}

The high 'a' value in flakes of the orange flaked jackfruit varieties suggests higher level of carotenoids in orange than yellow or white flakes. This was consistent with the principle component analysis bi-plot which located carotenoids in close proximity with orange flaked sections. The high levels of flake redness for orange flakes could probably be due to the high carotenoids content in orange flaked than in yellow or white flakes. This is in agreement with results reported by Englberger et al. (2006) who reported that darker yellow and orange colors in pandanus fruits are indicative of higher carotenoid levels. Also, high levels of carotenoids in orange flakes could be attributed to accelerated biosynthesis of carotenoids in orange flakes than in other jackfruit types caused by differences in genetic composition. The jackfruit sections did not affect flake color in all jackfruit types. Patil (2003) observed a uniform distribution of carotenoids in flakes from different sections of ripe jackfruits which was consistent with the results from this study.

Minor differences in color lightness, redness and yellowness were observed in white and yellow flaked jackfruit varieties suggesting closeness of the white and yellow flaked jackfruit varieties. Shyamalamma, Chandra, Hegde, \& Naryanswamy (2008) reported the existence of genetic diversity in some jackfruit cultivars. The strong colour intensity in the orange flakes suggests greater difference in genetic make up for orange flaked variety as compared to the yellow and white flaked varieties.

\subsection{Chemical Composition of Jackfruit Flake}

Titratable acidity varied significantly, the low titratable acidity observed in white flaked jackfruit could be attributed to the slow maturation process exhibited by this variety. Maturation leads to ripening and involves utilization of organic acids as sources of carbon skeletons for the synthesis of new compounds during ripening (Batista-Silva et al., 2018). Since white flaked jackfruit takes a relatively longer period to mature, it could imply that the long maturation period caused more organic acid break down in white flaked jackfruit compared to other jackfruit varieties of the same maturity or degree of ripeness. The low acid content observed in this study was consistent with results reported by Gwosami et al. (2011). The authors observed an average TA of $0.65 \%$ which was almost twice as much as that exhibited by white flakes. The difference might have been caused by differences in maturation periods.

Total soluble solids content, varied between jackfruit types and was lower in white compared to yellow or orange jackfruit flakes but was in the range of $20-27 \%$ reported by Goswami et al., (2011). However, it was slightly lower than $25-41 \%$ reported by Reddy et al. (2004) for jackfruit varieties of Indian Kerala region. Accumulation of soluble solids is in fruits postharvest, a result of physiological processes that lead to starch and pectin break-down into smaller soluble molecules (Beckles, 2012). Therefore, the high TSS content observed in orange flakes could be attributed to inherently high starch and pectin content in orange flakes compared to the yellow and white flakes.

The TSS-acid ratio varied with fruit type and section. With respect to fruit sections, the top section flakes in all 
jackfruit varieties showed relatively higher TSS- acid ratio than other sections, suggesting that flakes from top sections are tastier and therefore fruit ripening begins from the top section. This was clearly illustrated by PCA bi-plot in which total soluble solids, titratable acidity and TSS- acid ratio, which are the determinant of fruit taste, were located on the positive side of PCA1 together with orange jackfruit sections. This was consistent with Krüger et al. (2012) who reported that fruit flavor is mostly determined by contents of total acids, total soluble solids and their ratio. Mitra and Mani (2000) and Saxena, Bawa, \& Raju (2011) stated that jackfruits with TSS greater than $25^{\circ}$ brix and $0.3 \%$ titratable acidity are considered of high quality for dessert purposes. The results of this study were in agreement with the findings of Ketsa (1988) who reported that small fruits have higher TSS content and therefore high TSS-acid ratio than large fruits. Basing on the TSS:acid ratio, orange flakes could be more suitable for dessert preparations, whereas, the yellow and white flaked jackfruit varieties could be more suited for sweetened or dehydrated products.

The ascorbic acid content, varied significantly $(\mathrm{p}<0.05)$ between different fruit types, with white and orange flakes exhibiting twice as much ascorbic acid as in yellow flakes. The difference in the vitamin $\mathrm{C}$ content observed may be attributed to inherently reduced capacity to metabolize ascorbic acid in the ripe white and orange flaked jackfruit type. Rashim (2003) reported reduction in ascorbic acid content during ripening, which was attributed to degradation of the vitamin during the ripening processes. Therefore, relatively high levels of ascorbic acid in orange and white flaked jackfruit variety may be indicative of reduced capacity of utilizing ascorbic acid as carbon chain source during ripening.

The dry matter content did not vary among the jackfruit types and sections. Dry matter reported in this study was in agreement with values reported by Jagadeesh, et al., (2006) and Ibrahim, Islam, Helali, Alam, \& Shafique (2013) but were slightly higher than 17-20\% reported by Goswami, Hossain, Kader, \& Islam (2011) and Mitra \& Mani, (2000) for five jackfruit varieties grown in Bangladesh. Abong et al., (2010) associated high dry matter content of jackfruit flakes with high yields of chips. Therefore, flakes from the three jackfruit varieties could be used to make good quality chips.

\subsection{Textural Properties}

Flakes from the white flaked variety had lower total soluble solutes and were harder than those from the yellow and orange flaked jackfruit varieties. This was consistent with PCA results which located white flaked section close to flake hardness on one side and orange flakes close to TSS on the other side of the bi-plot. The difference in textural properties among flake types could be attributed to low activities of starch and pectin degrading enzymes in the white flakes compared to yellow and orange flakes. This is in agreement with Huber, Karakut \& Jeong (2001) who stated that fruit softening can be attributed to pectin depolymerization and dismembering mediated by pectinase enzymes active in ripe fruit. On the other hand flake resilience and hardness for all the three jackfruit varieties studied increased from top to bottom sections of the fruit, while TSS and TSS: TA increased in the opposite direction (Table 5). The variation in flake hardness among fruit sections could possibly be due to differences in the degree of ripeness of flakes from a particular fruit section. As the fruit ripens there is a general decrease in starch as it is being converted to sugars, this is consistent with an inverse relationship observed between TSS and textural properties of the flakes. Wongmetha, Lih-Shang, \& Liang (2015) also reported that as the fruit ripens, starch is degraded to sugars reducing its contribution towards flake hardness. The starch degradation and pectin de-polymerization and dismembering might be taking place at a relatively slower rate in the harder white flaked jackfruits than the yellow or orange flake types. The three jackfruit types therefore, could be suitable for processing different jackfruit based products. The harder textured white flakes could be suitable for processing yoghurt with jackfruit flake pieces. Mesurolle, Saint-Eve, Déléris, \& Souchon (2013) highlighted the importance of the harder fruit textural characteristics in processing of yoghurts or toppings with whole fruits or fruit pieces. The softer yellow and orange flakes on the other hand could be suitable for products like juices, fruit leathers and jams or jellies which require prior pulp extraction.

\subsection{Relationship between flake characteristics and fruit sections}

The bi plot located carotenoids, flake redness and TSS on the positive side of PC1. This signifies that flakes with high carotenoid content are deep red in color and sweeter in taste than those with low carotenoid content. Considering health benefits, orange jackfruit flakes are deep red in color Swami, Thakor, Haldankar \& Kalse 2012) and therefore richer in carotenoid content which is an important parameter for selecting varieties with more significant health promoting characteristics. The bi- plot located white sections to the negative side of PC1close to flake textural properties signifying a higher degree of hardness in white flakes than in orange and yellow flakes (Figure 2. This makes white flakes more suitable for use in products such as yogurts, desserts and toppings which require retention of tougher textural characteristics for the ripe fruit (Mesurolle, Saint-Eve, 
Déléris, \& Souchon, 2013). Yellow jackfruit flakes exhibited characteristics intermediate between the soft orange and hard white flake types. This makes yellow and orange flakes less suitable for minimally processed products because hardiness in fruit texture is one of the prime requirements in minimally processed fruit products (Ohlsson, 1994). In all jackfruit sections studied, flakes extracted from top sections leaned more towards the positive side of PC1 implying that they are tastier, attractive in color, higher in carotenoids and softer in texture. Flakes from bottom section on the other hand, leaned more towards to the negative side of PC1 signifying their being harder in texture and lighter in color. In this regard, flakes from top sections are better suited for products which require pulp extraction whereas those from middle and bottom section are more suitable for minimally processed jackfruit flakes. PCA bi-plot also showed that, sections of the same jackfruit are closely located regardless of variation in the analyzed parameter indicating that jackfruit variety has a greater effect on analyzed parameters than fruit sections.

\section{Conclusion}

The results suggest a relationship between jackfruit flake colour and some physico-chemical characteristics. Thus, flake color can be used as an indicator for jackfruit physical chemical properties and perhaps a predictor of the jackfruit performance in different processing applications.

\section{Acknowledgement}

This work was funded by the African Development Bank (AfDB) under the AfDB - HEST Project under the Ministry of Education and Sports and Food Technology and Business Incubation Centre, Makerere University.

\section{Conflict of interest: None}

\section{References}

Abong, G., Okoth, M., Imungi, J., \& Kabira, N. (2010). Evaluation of selected Kenyan potato cultivars for processing into potato chips. Agriculture \& Biology Journal of North America, 1(5), 886-893. https://doi.org/10.5251/abjna.2010.1.5.886.893

AOAC. (1995). Official Methods of Analysis (16 ed.). Vitamin C determination, 967.21. Washington DC, USA: Association of Official Analytical Chemists.

APAARI. (2012). Jackfruit Improvement in the Asia-Pacific Region - A Status Report. Asia-Pacific Association of Agricultural Research Institutions. Bangkok, Thailand.

Azad, A. K., Jones, J. G., \& Haq, N. (2007). Assessing morphological and isozyme variation of jackfruit (Artocarpus heterophyllus Lam.) in Bangladesh. Agroforest Systems, 71(2), 109-125. https://doi.org/10.1007/s10457-007-9039-8

Balamaze, J., Muyonga, J. H., \& Byaruhanga, Y. B. (2019). Production and Utilization of Jackfruit (Artocarpus heterophyllus) in Uganda. African Journal of Food Agriculture, Nutrition \& Development, 19(2), 14289-14302. https://doi.org/10.18697/ajfand.85.17290

Batista-Silva, W., Nascimento, V., Medeiros, D., Nunes-Nesi, A., Ribeiro, D., ... Zsögön, A. (2018). Modifications in Organic Acid Profiles During Fruit Development and Ripening: Correlation or Causation? Frontiers in Plant Science, 9(1689). https://doi.org/ 10.3389/fpls.2018.01689

Beckles, D. M. (2012). Factors affecting the postharvest soluble solids and sugar content of tomato (Solanum lycopersicum L.) fruit. Postharvest Biology and Technology, 63(1), 129-140. https://doi.org/10.1016/j.postharvbio.2011.05.016

Beguma, R., Azizb, M., Uddinb, Y., \& Yusof. (2014). Characterization of Jackfruit (Artocarpus heterophyllus) Waste, Pectin as Influenced by Various Extraction Conditions. Agriculture and Agricultural Science Procedia, 2, 244-251. https://doi.org/ 10.1016/j.aaspro.2014.11.035.

Englberger, L., Aalbersberg, W., Dolodolotawake, U., Schierle, J., Humphries, J., ... Iuta, T. (2006). Carotenoid content of pandanus fruit cultivars and other foods of the Republic of Kiribati. Public Health Nutrition, 9(5), 631-643. https://doi.org/10.1079/PHN2005892

Goswami, C., Hossain, M., Kader, A., \& Islam, R. (2011). Assessment of Physicochemical Properties of Jackfruits (Artocarpus heterophyllus Lam) Pulps. Journal of Horticulture, Forestry and Biotechnology, 15(3), 26-31.

Hartman, C. F., \& Thomas, G. (2012). Decrease in Fruit Moisture Content Heralds and Might Launch the Onset of Ripening Processes. Journal of Food Science, 77(10), 365-375. https://doi.org/10.1111/j.1750-3841.2012.02910.x 
Huber, D., Karakurt, Y., \& Jeong, J. (2001). Pectin degradation in riprnning and wounded fruits. Brazilian Journal of Plant Physiology, 13(2), 224-241. https://doi.org/10.1590/S0103-31312001000200009

Ibrahim, M., Islam, S., Helali, M., Alam, A. K., \& Shafique, M. Z. (2013). Morphological fruit characters and nutritional food value of different jackfruit (Artocarpus heterophyllus Lam.) cultivars in Rajshahi region of Bangladesh. Bangladesh Journal of Scientific \& Industrial Research, 48(4), 287-292. https://doi.org/10.3329/bjsir.v48i4.18280

Jagadeesh, S., Laxminarayan, H., Swamy, G., Reddy, B., SKiran, K. G., \& Basavaraj, N. (2006). Influence of physico-chemical parameters of jackfruit bulbs on chips quality. CSBE/SCGAB 2006 Annual Conference (pp. 06-216). Edmonton Alberta : The Canadian Society for Engineering in Agricultural, Food, Environmental and Biological Systems.

Jagadeesh, S., Reddy, B., Basavaraj, N., Swamy, S., \& Laxminarayan, H. (2010). Variability studies in physico-chemical qualities of jackfruit (Artocarpus heterophyllus Lam.) of coastal zone of Karnataka. Karnataka Journal of Agricultural Sciences, 23(2), 293-297.

Ketsa, S. (1988). Effects of fruit size on juice content and chemical composition of tangerine. Journal of Horticultural Sciences, 63(1), 171-174. https://doi.org/10.1080/14620316.1988.11515843

Kruger, E. Josuttis, M., Nestby, R., Toldam-Andersen, T. B., Carlene C., \& Mezzetti B. (2012). Influence of growing conditions at different latitudes of Europe on strawberry growth performance, yield and quality. Journal of Berry Research, 2(3), 143-157. https://doi.org/10.3233/JBR-2012-036

Mannan, M., Gazi, M., \& Mia, M. (2006). Problem Confrontation in Off-Season Jackfruit Cultivation in South Western region of Bangladesh. South Asian Journal of Agriculture, 1(2), 108-109.

Mesurolle, J., Saint-Eve, A., Déléris, I., \& Souchon, I. (2013). Impact of Fruit Piece Structure in Yogurts on the Dynamics of Aroma Release and Sensory Perception. Molecules, 18, 6035-6056. https://doi.org/10.3390/molecules 18056035

Mitra, S., \& Mani, D. (2000). Conservation and Utilization of genetic resources in Jackfruit (Artocarpus heterophyllus L)-A potential Underutilized fruit. Acta Horticulturae, 523, 229-232. https://doi.org/10.17660/ActaHortic.2000.523.29

Ohlsson, T. (1994). Minimal processing preservation methods of the future: an overview. Trends in Food Science and Technology, 5(11), 341-344. https://doi.org/10.1016/0924-2244(94)90210-0

Ong, B. T., Hamid, N., Osman, A., \& Kong, Y. W. (2006). Chemical and flavour changes in jackfruit (Artocarpus heterophyllus Lam.) cultivar J3 during ripening. Postharvest Biology and Technology, 40(3), 79-286. https://doi.org/10.1016/j.postharvbio.2006.01.015

Patil, R. S. (2003). Studies on physico-chemical composition, storage, processing and waste utilization of jackfruit (Artocarpus heterophyllus Lam). PhD thesis. Dr. Balasaheb Savant Konkan Krishi Vidyapeeth, Dapoli Agricultural University, India. Retrieved from http://krishikosh.egranth.ac.in/handle/1/5810015328

Pinheiro-santana, H., Stringheta, P., Branda, S. C., Paez, H. H., \& Queiroz, V. M. (1998). Evaluation of total carotenoids, alpha and beta carotene in carrots(Daucus carota L.) during home processing. Food Science and Technology, 18(1). https://doi.org/10.1590/S0101-20611998000100009.

Rangana,S. (1995). Hand Book of Analysis and Quality Control for Fruit and Vegetable Production. New Delhi: Tata McGraw-Hills.

Reddy, B. M. C., Patil, P., Kumar, S. S., \& Govindaraju, L. R. (2004). Studies on Physico-Chemical Characteristics of Jackfruit Clones of South Karnataka. Karnataka Journalof Agricultural Sciences, 17(2), 279-282.

Robert, L., \& Bradley, J. (2010). Compositional Analysis of Foods. In S. N. Suzanne (ed.), Food Analysis. Madison: Springer.

Rosnah, S., Chia, S., Chin, N., Noraziah, M., \& Osman, H. (2009). Chemical composition of the jackfruit juice (Artocarpus) cultivar J22 duriung storage. Journal of Applied Sciences, 9(17), 3202-3204. https://doi.org/10.3923/jas.2009.3202.3204

Sakimin, S. Z., Patre, S. S., Juraimi, A. S., Alam, M. A., \& Aslani, F. (2017). Application of ascorbic acid in maintenance of minimally processed product quality of jackfruit (Artocarpus heterophyllus lam). Bangladesh Journal of Botany, 46(1), 413-418. 
Sarker, S. R., \& Zuberi, M. I. (2011). Assessment of morphological characters and ethnobotanical survey of jackfruit germplasm in two sites of Rajshahi, Bangladesh. Geneconserve, 10(40), 110-128.

Saxena, A., Bawa, A. S., \& Raju, P. S. (2011). Jackfruit (Artocarpus heterophyllus Lam.). Mysore, India: Woodhead Publishing Limited. https://doi.org/10.1533/9780857092885.275

Shyamalamma, S., Chandra, S. B., Hegde, M., \& Naryanswamy, P. (2008). Evaluation of genetic diversity in jackfruit (Artocarpus heterophyllus Lam.) based on amplified fragment length polymorphism markers. Genetic \& Molecular Research, 7(3), 645-656. https://doi.org/10.4238/vol7-3gmr457

Singh, I. S., \& Srivastava, A. K. (2000). Genetic variability in jackfruit. IPGRI Newsletter for Asia, the Pacific and Oceania, 31, 22-23.

Swami, S. B., Thakor, N. J., Haldankar, P. M., \& Kalse, S. B. (2012). Jackfruit and Its Many Functional Componentsas Related to Human Health: A Review. Comprehensive Reviews in Food Science and Food Safety, 11(6), 565-576. https://doi.org/10.1111/j.1541-4337.2012.00210.x.

Ullah, M. A., \& Haque, M. A. (2008). Studies on fruiting, bearing habit and fruit growth of jackfruit germplasm. Bangladesh Journal of Agricultural Research, 33(3), 391-397. https://doi.org/10.3329/bjar.v33i3.1598

Vazhacharickal, P., Sajeshkuma, N., Jiby, J. M., Ajesh, C., Benchamin, A., \& Renjith, J. M. (2015). Chemistry and medicinal properties of jackfruit (artocarpus heterophyllus): A review on current status of knowledge. International Journal of Innovative Research and Review, 3(2), 83-95.

Wongmetha, O., Ke, L-S., \& Liang, Y-S. (2015). The changes in physical, bio-chemical, physiological characteristics and enzyme activities of mango cv. Jinhwang during fruit growth and development. NJAS: Wageningen Journal of Life Sciences, 7(12), 72-73. https://doi.org/10.1016/j.njas.2014.10.001

\section{Copyrights}

Copyright for this article is retained by the author(s), with first publication rights granted to the journal.

This is an open-access article distributed under the terms and conditions of the Creative Commons Attribution license (http://creativecommons.org/licenses/by/4.0/). 